\title{
Structural Equation Model of Acceptance Cloud Learning for Sustainability Usage in Higher Education Institutes
}

\author{
https://doi.org/10.3991/ijet.v14i10.10045 \\ Supparang Ruangvanich ${ }^{(\varpi)}$, Pallop Piriyasurawong \\ King Mongkut's University of North Bangkok, Bangkok, Thailand \\ s5902052956045@email.kmutnb.ac.th
}

\begin{abstract}
The study is to propose the structural equation model for sustainability in higher education about the use of cloud learning based on the technology acceptance model. Also, this well-known implemented-model was developed by Davis et al.'s technology acceptance model (TAM). The researchers instituted the hypothesized internal hierarchy among content quality, cloud computing, and social cloud for sustainability usage. The informed hypothesis was obtained from a scientific method known as the systematic literature review. After that, the higher education institute in Thailand has given attention to the burgeoning of cloud learning due to the additional demand in line with technology development for tertiary instruction in the country.

Nevertheless, the strength of its usage is not very outstanding, and there is a need to understand the student's attitude on the sustainability usage of cloud learning from the perspectives of the technology acceptance model. This study indicated that sustainability usage was a significant predictor towards student to use cloud learning. As a result, it is seen that pupils' attitude plays a vital role in contributing to the sustainability to use cloud learning. The consequence of this study is expected to improve and upgraded cloud learning to be beneficial according to the needs of the students.
\end{abstract}

Keywords - Structural equation model, acceptance technology, cloud learning, sustainability, higher education institutes

\section{Introduction}

The higher education institutes in Thailand aim to improve and incorporate diverse types of learning resources for formal and informal learning [1]. These institutes construct the infrastructure and service systems besides build ubiquitous individualized learning environments for the $21^{\text {st }}$ century [2]. Meanwhile, the cloud computing should build upon learning network. For instance, a lifelong learning platform is by integrating resources in various networks; cloud service provides users with flexible, 
on-demand and low-cost information services via the Internet. Therefore, to build intelligent education cloud platforms not only can meet the demands of the development plan, but also can help to build a smart or intelligent city. An intelligent city can proactively facilitate the building of intelligent educational, cultural systems and the development of intelligent education.

To reach the intelligent education, it should implement cloud learning in the institutes. Cloud learning is gaining popularity worldwide, reducing the temporal and spatial problems associated with the traditional form of education [3]. The primary aspects behind using cloud learning are not only to improve access to education, and quality of learning, but also to reduce the cost and improve the cost-effectiveness of education. The growth of the cloud market can be demonstrated by the fact that the global cloud market is expected to reach 300 billion dollars by 2021 growing at a cumulative average growth rate of $21 \%$ this year [4]. In addition to this, almost $40 \%$ of this will come from software as a service (SaaS) with a quarter to come from what Gartner calls cloud business process service (BPaaS) - delivering business process outsourcing (BPO) and $22 \%$ to come from infrastructure as a service (IaaS). However, it will outstrip BPaaS by 2021 according to Gartner's prediction. In three years total public cloud service revenues will surpass $\$ 300$ billion, with SaaS accounting for $38 \%$ of that total, IaaS $27 \%$ and BPaaS $19 \%$. SaaS will also hit $45 \%$ of total application software spending by 2021. Nevertheless, Platform as a service (PaaS) will comprise $8 \%$ of the total public cloud market this year at relatively princely 15 billion dollars, while cloud management and security services will total 10.5 billion dollars.

Regardless of quite a few benefits of cloud learning such as improving access to education and training, refining the superiority of learning, sinking the cost and improving the cost-effectiveness of education, retentive students in such platforms is a crucial challenge with an in-height attrition degree. Hence, the significant concentration of research remains on how to retain cloud learning users and propose the sustainability of cloud learning in higher education institutes in Thailand.

\section{Proposed Model}

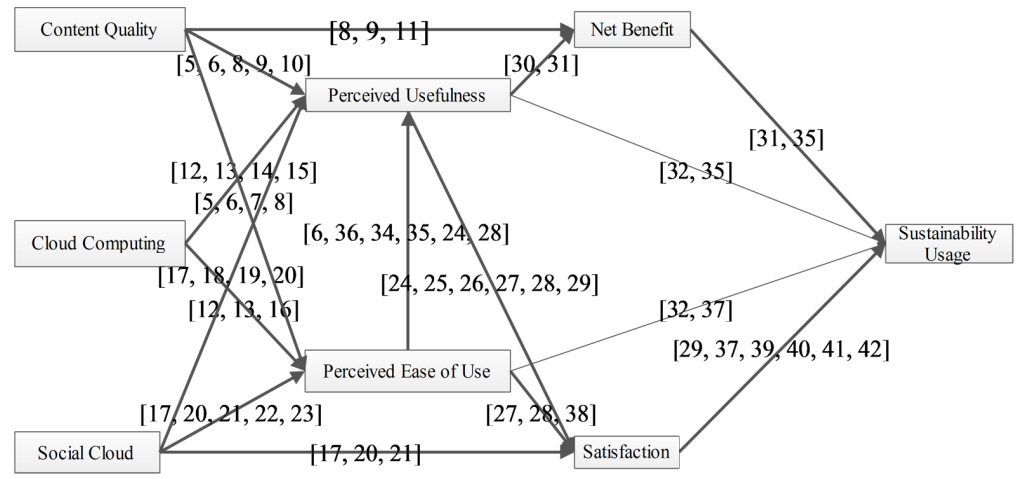

Fig. 1. Proposed model for acceptance cloud learning for sustainability in higher education institutes 
Table 1. Critical factors for acceptance cloud learning for sustainability in higher education institutes

\begin{tabular}{|c|c|c|}
\hline Factors & Description & References \\
\hline $\begin{array}{l}\text { Content quality } \\
\text { (CQ) }\end{array}$ & $\begin{array}{l}\text { The standards of content quality representing as accuracy, renewal, integ- } \\
\text { rity, briefly and availability and easily accessible by the user (student) or } \\
\text { the administrator (teacher). }\end{array}$ & {$[5-11]$} \\
\hline $\begin{array}{l}\text { Cloud computing } \\
\text { (CC) }\end{array}$ & $\begin{array}{l}\text { Cloud computing is the use of several services, for example, software } \\
\text { development platforms, servers, storage, and software, over the internet, } \\
\text { frequently mentioned to as the cloud. It is mutual to classify cloud } \\
\text { computing services as infrastructure as a service (IaaS), platform as a } \\
\text { service (PaaS) or software as a service (SaaS). }\end{array}$ & {$[12-16]$} \\
\hline $\begin{array}{l}\text { Social cloud } \\
\text { (SC) }\end{array}$ & $\begin{array}{l}\text { It is interactive and collaborative behavior between computer users. } \\
\text { Personal computing is an individual user activity in that one user general- } \\
\text { ly commands computing. In the social cloud, the Internet allows users to } \\
\text { interact through many mediums, including social media sites. blogs, } \\
\text { microblogs, multiplayer games, Wikis, instant messaging and open-source } \\
\text { development }\end{array}$ & {$[17-23]$} \\
\hline $\begin{array}{l}\text { Perceived useful- } \\
\text { ness } \\
(\mathrm{PU})\end{array}$ & $\begin{array}{l}\text { It is the degree to which an individual believes that using a particular } \\
\text { system would enhance his/her job performance. }\end{array}$ & {$[24-33]$} \\
\hline $\begin{array}{l}\text { Perceived ease of } \\
\text { use } \\
\text { (PEOU) }\end{array}$ & $\begin{array}{l}\text { The perceived level of the effort necessary for the use of the cloud learn- } \\
\text { ing. }\end{array}$ & $\begin{array}{l}{[6,24,32} \\
34-38]\end{array}$ \\
\hline $\begin{array}{l}\text { Net benefit } \\
(\mathrm{NB})\end{array}$ & It was exaggerated by system use and by user satisfaction with the system. & {$[31,33]$} \\
\hline $\begin{array}{l}\text { Satisfaction } \\
\text { (SA) }\end{array}$ & It is the opinions of the students on cloud learning. & $\begin{array}{l}{[29,37,39-} \\
42]\end{array}$ \\
\hline $\begin{array}{l}\text { Sustainability } \\
\text { Usage } \\
\text { (SU) }\end{array}$ & The level of sustainability usage of cloud learning. & \\
\hline
\end{tabular}

\section{$3 \quad$ Literature Review}

\subsection{Content quality}

Aladwani and Palvia [43] well-defined the overall concept of website quality as users' evaluation of the website's features meeting users' requirements and reflecting overall excellence of the website. The researchers considered users' beliefs about content quality attributes (for example accuracy, clarity, conciseness, and so on) as an essential component in their conceptualization.

The learning content refers to any designed digital source (such as lectures, courses, assignments, images, quizzes, and so on), and the quality of content refers to the suitability of content to users regarding reliability, currentness, and appropriateness [44]. Learning content quality is one of the main components of the cloud learning success, because that the main idea of using this system is learning, so if the quality of learning content does not be at a certain level, the goal of cloud learning alongside its users (learning efficiently and effectively) will not be attained. Content quality is the quality of the system output and measures semantic success. Some of the indicators for measuring the content quality are [45]: 
- Provide understandable content

- Provide updated content

- Provide accurate and true content

- Provide concise content

- Provide organized content

- Provide required content

- Provide on-time content

- Provide relevant content

- Provide useful content

- Provide comprehensive content

According to [5], the researchers worked to understand the attitude of Turkish EFL learners towards technology and to determine the role of these factors in the academic achievement of the participants. Moreover, [6] was to investigate the effect of SelfEfficacy, Subjective Norm, Enjoyment, Computer Anxiety and Experience on students' Perceived Ease of Use (PEOU) and Perceived Usefulness (PU) of an eportfolio system and their Behavioural Intention (BI) to use the system for learning. [7] was to propose a unified model integrating the technology acceptance model (TAM), task fit technology (TTF) model, MOOCs features and social motivation to investigate continuance intention to use MOOCs. [8] tried to examine an integrated model of TAM and D\&M to explore the effects of quality features, perceived ease of use, perceived usefulness on users' intentions and satisfaction, alongside the mediating effect of usability towards the use of e-learning in Iran. [9] proposed and empirically examined a new construct, compatible quality of social media content, which complements to information by expanding prior online content quality research elsewhere the traditional focus on non-fit quality beliefs. [10] proposed an assessment of geometrical content of 3D models for Heritage Building Information Modelling (hBIM) without reference measurements and independently of the data acquiring method or point cloud resolution. [11] studied the interplay between network investment and content quality on the Internet, and investigates the implications to the net neutrality regime.

\subsection{Cloud computing}

Cloud is a term that emerged in the telecommunication field when virtual private network (VPN) services for data communications were established in the early 1990s [46]. Similarly, cloud computing provides shared services that are allocated dynamically to meet the requirements of the organizations and users [47]. The National Institute of Standards and Technology (NIST) defined cloud computing as a model for permitting ubiquitous, appropriate, on-demand network admission to a shared pool of configurable computing resources that could be provisioned promptly and released with minimal management effort or service provider interaction [48]. According to [46] cloud computing is possessing the following essential features:

- Resources are self-provisioned automatically depending on-demand 
- Service charges depend on access and usage of the monitored resources

- Resources are elastic and are scaled depending on the load

- Accessible from any networked device

- Resources can be pooled enabling independent multi-tenancy

Various service models or cloud computing services stacks are used to deliver these services. These comprise of Infrastructure as a Service (IaaS), Platform as a Service (PaaS) and Software as a Service (SaaS). The service models are classified according to the service type and with specific responsibilities being placed on the client and service providers respectively. The IaaS models deliver computing services for data security, storage and computing resources such as Virtual Machine (VM) for running applications [49]. The VM is scaled dynamically to meet the varying user requirements, and a pay-as-you-go model is used to charge for the services [46].

Learning needed for a new generation of students are different from their predecessors [50]. As a result, the researchers favor increased use of technology and its successful applications [51]. The cloud computing applications can benefit students by providing them with quick connections to the core materials and with each other. According to [50], cloud computing can provide higher educations with the following benefits: (a) allowing for the use of the users own personal workspace; (b) facilitating interactive teaching and learning communities; (c) no need for backup due to shared cloud storage; and (d) the availability of large amounts of processing power. Cloud computing can also provide a digital learning environment, personal portfolio, and web-based self-service options for students and faculty alike. The potential gains that cloud computing can bring to the higher learning environments are numerous while the potential risks include the concerns about security, privacy, and issues related to the reliability and performance of the technology [52]. Cloud computing can also provide a digital learning environment, personal portfolio, and web-based self-service options for students and faculty alike. In [52], the benefits of cloud computing for students are described as: (a) ubiquitous availability of online applications; (b) flexibility to create structured learning environments; (c) support for mobile learning; and (d) scalability.

According to [12], the researchers attempt to develop a hybrid model to forecast motivators influencing the acceptance of cloud computing services by information technology (IT) professionals. Then, [13] focused on the relations between variables recognized in the literature that are measured to be manipulating use and perceptions of technology for apprentice students of technology at a mid-sized university in Southeast Michigan. [14] presented a survey of IoT and Cloud Computing with a focus on the security issues of both technologies. [15] aimed to investigate the antecedents and consequences of cloud computing adoption in education to achieve knowledge management. [16] examined external auditors' perceptions of the reasons why organizations do or do not adopt cloud computing. 


\subsection{Social cloud}

Social clouds deliver the competence to share resources among participants within a social network-leveraging on the trust relationships already existing between such participants. In such a system, users can trade resources between each other rather than make use of capability offered at a (centralize) data center. Although such an environment has significant potential for improving resource utilization and making available additional capacity that remains dormant, incentives for sharing remain a significant hurdle limiting its useful. Thus, a social cloud is a blend of both cloud computing and social computing. With social networks, individual users suffer from limited capabilities. The various cloud providers available are Amazon EC2/S3 [53], Google App Engine [54], Microsoft Azure [55], and other small-scale open Clouds like Nimbus [56] and Eucalyptus [57]. These clouds provide access to resources using pre-dominantly posted price mechanisms. A social cloud is defined in [58] as a scalable computing model in which the virtualized resources contributed by a user is dynamically provisioned amongst a group of friends. A social cloud is shown in Figure 3.

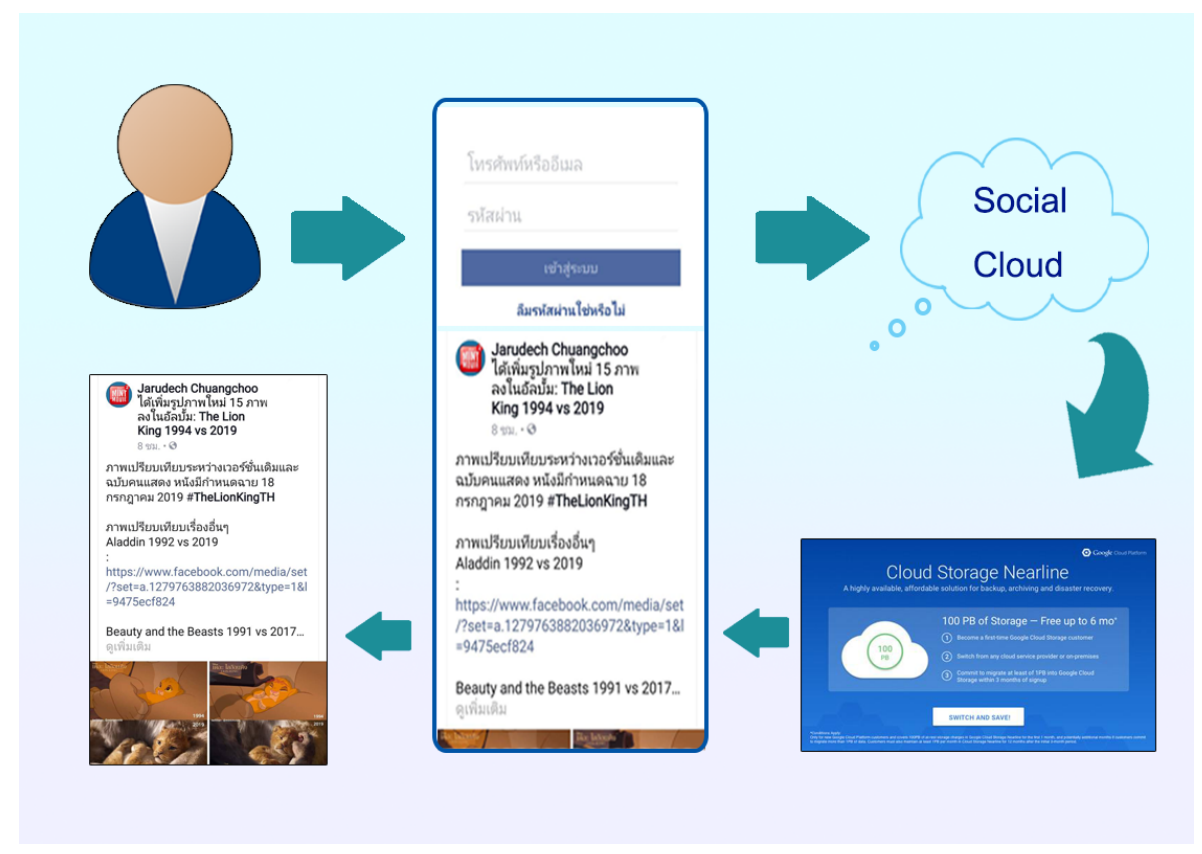

Fig. 2. Social cloud

[17] recommended that the use of Apps in m-learning and the use of cloud services can boost the ease and access to online learning to users and organizations. [18] presented a container-based cloud resource bartering (CRB) model for sharing user's computational resources through a social network. In our approach, the researchers had integrated a Facebook account with the computational cloud to enable tenants to 
share their unused cloud resources with other users. [19] was to understand the recent trends of social media use, the phenomenon of distractions and factors out convincing students for the academic use of social media. [20] also presented the system design, development, and analysis. The technology was based on the BOINC open source software, their hybrid Cloud, Facebook Graph API and their development in a new Facebook API, SocialMedia. [21] summarized under their concept of crowd social media computing, the researchers investigated and modeled the characteristics of the social media ecosystem, the researchers discussed the characteristics of crowd computing, and then the researchers demonstrated how crowd computing could play a pivotal role in emerging social media applications. The researchers also propose a new approach to evaluate the impact of crowd computing on the issue of social media Return of Investment (ROI). [23] studied and served as a baseline by which cloud service providers, the ministry of education, and educational institutions could make strategic and healthy decisions about adoption of cloud-based technology in educational environments. [22] found that the most causal factors for use or cloud computing are technology readiness, individual readiness, organization support, environment and, security and privacy.

\subsection{Perceived usefulness}

Perceived usefulness was introduced by Davis [59] as a TAM construct [7, 60-63], defined as the perceived degree to which an individual believes that via a specific service or system will improve his or her task performance [59, 64]. Davis' definition focused on the aspect of individual performance. Chang [65] recognized perceived usefulness as performance expectancy. The researcher confirmed that with the help of mobile library apps to find university libraries' data, users could improve their work performance .Therefore, their use intention is stronger. Sheikhshoaei and Oloumi [66] found that perceived usefulness affects the attitude toward librarians' IT acceptance. Kim [67] noted that positive relationships exist between perceived usefulness and intention to use in mobile library service. Xu et al. [68] indicated that perceived usefulness positively influences the actual intention to use digital library services .

[6] was to investigate the influence of Self-Efficacy, Subjective Norm, Enjoyment, Computer Anxiety and Experience on students' Perceived Ease of Use (PEOU) and Perceived Usefulness (PU) of an e-portfolio system and their Behavioral Intention (BI) to use the system for learning. [36] explored the moderating effect of tie (perceived similarity) on the allocation of ease of use (quantity of strength essential to use library resources) and usefulness (the degree to which using library resources would develop performance) from print resources to automated resources, with the view in mind of facilitating the effective use of online automated resources in Chinese university libraries. [34] studied scopes of PU and PEU of an e-government service, and measured the influence of PU, PEU, Social Norms, Facilitating Conditions, and Trust in the direction of personal acceptance of a new e-government service in a developing country. [35] aimed to explore and make user satisfaction model for elearning using smartphone applications in Mulawarman University. [24] had implemented enterprise resource planning (ERP) systems to have a standardized infor- 
mation system (IS) in their particular organizations and to re-engineer their business processes. [25] studied typically predict behavioral outcomes by investigating the relationship between attitudes and intentions, though the intention may not be the superlative predictor of actual behavior. [26] studied typically predict behavioral outcomes by investigating the relationship between attitudes and intentions, though the intention may not be the greatest predictor of precise behavior. [27] proposed a detailed framework to measure instructors' satisfaction of using LMS. The findings prove that perceived usefulness and service quality are taking the highest share on affecting the instructor satisfaction. [28] aimed to examine credit receiving university students' motivation to use K-MOOCs. [29] was to identify factors by proposing a Technology Acceptance Model of an Academic and Administrative Information System. University population is described, both private and public. [30] examining the implications of the explosion of new media and web technologies, which may offer the potential for improving food risk and benefit communication. [31] focused on EA service capability and developed and tested a new research model that explains how EA service brings benefits to organizations. [32] was to find out whether using a specially developed isometric template helps students to reduce time and efforts while drawing isometric drawing. [33] explored the differences in the process by which local, national and foreign branded banks can integrate their online platforms into their relational efforts.

\subsection{Perceived ease of use}

Perceived ease of use was presented as a TAM construct [69] and is defined as the degree that using a specific technology will be permitted from determination $[59,64]$. Perceived ease of use is definite as the degree to which individuals feel free from attractive in mental and physical efforts for a mobile library app. Studies above have supported the notion that there are positive relationships between perceived ease of use and assertiveness, perceived ease of use and usefulness, and perceived ease of use and intention to use. Joo and Choi [70] found that perceived ease of use is an essential factor of perceived usefulness and attitude in apprentices' variety of online library resources when academic accomplishment tasks. Supplementary, a positive relationship between perceived ease of use and intention to use has been confirmed in mobile library services [67]. Additionally, Sheikhshoaei and Oloumi [66] found that perceived ease of use affects perceived usefulness and attitude to use for librarians' IT acceptance. [37] was to investigate the factors, which directly or indirectly influence mobile applications' adoption by users. [32] was to investigate the factors, which directly or indirectly influence mobile applications' adoption by users. [38] was to search and examine the factors which influence customer satisfaction towards Internet banking. [27] proposed a detailed framework to measure instructors' satisfaction of using LMS. [29] was to identify which factors influence on engineering students about their acceptance of an academic administrative information system in private universities in Lima, Peru. 


\subsection{Satisfaction}

Revisions above have definite that satisfaction is positively associated with the intention of using the service [68, 71]. For instance, Xu et al. [68] found that user satisfaction positively influences the actual intention to use digital library services. Similarly, Bhattacherjee [71] demonstrated that initial satisfaction with an information system has positive effects on the intention to keep using the system. Additionally, Park and del Pobil [72] found that service and system satisfaction has a significant effect on the behavioral intention to use mobile communication services.

\subsection{Net benefit}

The ultimate touchstone of system success is the net benefits the system generates for the organization, including cost savings, expanded markets, and time savings [73]. It may be an essential concern for organizations to encourage positive attitudinal change or careful use of the system, but eventually, the goal is to bring about an increase in net benefits .However, researchers of mandatory software use rarely included net benefits in their models, with one exception being Lee and Park [74]. The researcher's study found that user satisfaction with the system is positively related to perceived market performance. Extensive, studies have shown a significant satisfaction-performance relationship [73, 74] IS success model incorporated this link, as well as a relationship between system users and net benefits. Use of the system is purported to generate positive or negative net benefits, which, through a feedback loop, can impact future use behavior and satisfaction.

\section{$4 \quad$ Hypothesis}

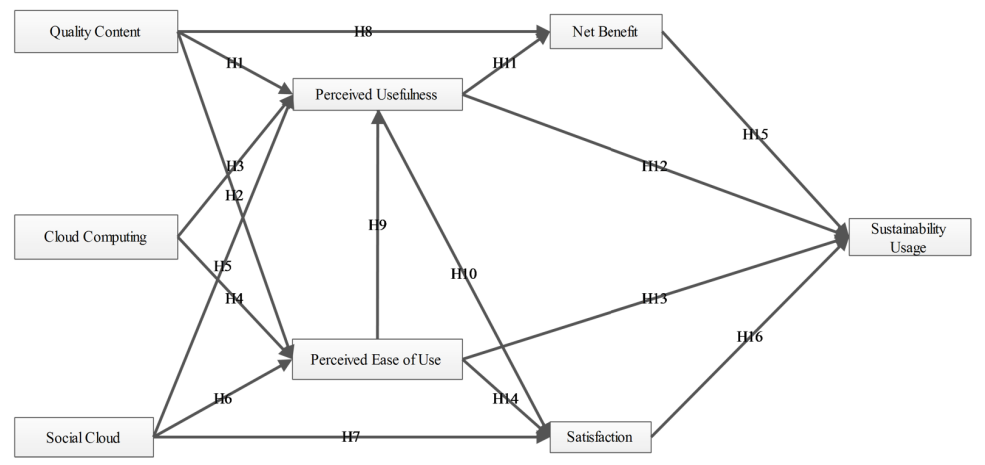

Fig. 3. The hypothesis of the proposed acceptance cloud learning for sustainability in higher education institutes covering TAM concepts

The followings are the hypothesis of proposed acceptance cloud learning for sustainability in higher education institutes covering TAM concepts

- H1: Content quality has a positive association with perceived usefulness. 
- H2: Content quality has a positive association with perceived ease of use.

- H3: Cloud computing has a positive association with perceived usefulness.

- H4: Cloud computing has a positive association with perceived ease of use.

- H5: Social cloud has a positive association with perceived usefulness.

- H6: Social cloud has a positive association with perceived ease of use.

- H7: Social cloud has a positive association with satisfaction.

- H8: Content quality has a positive association with net benefit.

- H9: Perceived ease of use has a positive association with perceived usefulness.

- H10: Perceived usefulness has a positive association with satisfaction.

- H11: Perceived usefulness has a positive association with net benefit.

- H12: Perceived usefulness has a positive association with sustainability usage.

- H13: Perceived ease of use has a positive association with sustainability usage.

- H14: Perceived ease of use has a positive association with satisfaction.

- H15: Net benefit has a positive association with sustainability usage.

- H16: Satisfaction has a positive association with sustainability usage.

\section{Conclusion}

This study is attempting to apply newly proposed sustainability for cloud learning framework to enhance the higher education institutes in Thailand. The findings of this research found that the number of users uses cloud learning is low. As well the communication between the students and faculty member by mean of technology is likewise low and is not motivated by the actual facilities used by users in their daily life, and user's expectations compared to the real deal do not reach the actual user's needs. The research used an experiment through the implementation of the new system and used the sampling test, and it is a reliable tool to examine and measure user satisfaction.

To conclude, the overall finding confirmations are quality content, cloud computing, social cloud, perceived ease of use, perceived usefulness, net benefit, satisfaction, and sustainability usage. As critical success factors, the impact of the use of sustainability for cloud learning in higher education institutes could be accompanied to validate this finding by developing an instrument and take a survey of higher education institutes in Thailand.

\section{Acknowledgement}

The research was partially supported by the Graduate Thesis Research Grant (GTRG) from the Graduate College, King Mongkut's University of Technology North Bangkok under award number 129/fiscal year 2018. You may mention here granted financial support or acknowledge the help you got from others during your research work. 


\section{$7 \quad$ References}

[1] Z. Shana and E. S. Abulibdeh, "Cloud Computing Issues for Higher Education: Theory of Acceptance Model," iJET, vol. 12, pp. 168-184, 2017. https://doi.org/10.39 91/ijet.v12i11.7473

[2] E. v. Laar, A. J. A. M. v. Deursen, J. A. G. M. v. Dijk, and J. d. Haan, "21st-century digital skills instrument aimed at working professionals: Conceptual development and empirical validation," Telematics and Informatics, vol. 35, pp. 2184-2200, 2018. https://doi.org/10.1 016/j.tele.2018.08.006

[3] V. Muniasamy, I. M. Ejalani, and Anandhavalli, "Moving towards Virtual Learning Clouds from Traditional Learning: Higher Educational Systems in India," IJET, vol. 9, pp. 70-76, 2014. https://doi.org/10.3991/ijet.v9i9.4183

[4] Gartner. (2018, November 20). Gartner Forecasts Worldwide Public Cloud Revenue to Grow 17.3 Percent in 2019. Available: https://www.gartner.com/en/newsroom/pressreleases/2018-09-12-gartner-forecasts-worldwide-public-cloud-revenue-to-grow-17percent-in-2019

[5] R. Cakır and E. Solak, "Attitude of Turkish EFL Learners towards e-Learning through Tam Model," Procedia - Social and Behavioral Sciences, vol. 176, pp. 596 - 601, 2015. https://doi.org/10.1016/j.sbspro.2015.01.515

[6] F. Abdullah, R. Ward, and E. Ahmed, "Investigating the influence of the most commonly used external variables of TAM on students' Perceived Ease of Use (PEOU) and Perceived Usefulness (PU) of e-portfolios," Computers in Human Behavior, vol. 63, pp. 75-90, 2016. https://doi.org/10.1016/j.chb.2016.05.014

[7] B. Wu and X. Chen, "Continuance intention to use MOOCs: Integrating the technology acceptance model (TAM) and task technology fit (TTF) model," Computers in Human Behavior, vol. 67, pp. 221-232, 2017. https://doi.org/10.1016/j.chb.2016.10.028

[8] H. Mohammadi, "Investigating users' perspectives on e-learning: An integration of TAM and IS success model," Computers in Human Behavior, vol. 45, pp. 359-374, 2015. https://doi.org/10.1016/j.chb.2014.07.044

[9] A. M. Aladwani, "Compatible quality of social media content: Conceptualization, measurement, and affordances," International Journal of Information Management, vol. 37, pp. 576-582, 2017. https://doi.org/10.1016/j.ijinfomgt.2017.05.014

[10] A. Fryskowska and J. Stachelek, "A no-reference method of geometric content quality analysis of 3D models generated from laser scanning point clouds for hBIM," Journal of Cultural Heritage, 2017. https://doi.org/10.1016/j.culher.2018.04.003

[11] E. Baranes, "The interplay between network investment and content quality: Implications to net neutrality on the Internet," Information Economics and Policy, vol. 28, pp. 57-69, 2014. https://doi.org/10.1016/j.infoecopol.2014.07.002

[12] S. K. Sharma, A. H. Al-Badi, S. M. Govindaluri, and M. H. Al-Kharusi, "Predicting motivators of cloud computing adoption: A developing country perspective," Computers in Human Behavior, vol. 62, pp. 61-69, 2016. https://doi.org/10.1016/j.chb.2016.03.073

[13] S. Ashtari and A. Eydgahi, "Student perceptions of cloud applications effectiveness in higher education," Journal of Computational Science, vol. 23, pp. 173-180, 2017. https://doi.org/10.1016/j.jocs.2016.12.007

[14] C. Stergiou, K. E. Psannis, B.-G. Kim, and B. Gupta, "Secure integration of IoT and Cloud Computing," Future Generation Computer Systems, vol. 78, pp. 964-975, 2018. https://doi.org/10.1016/j.future.2016.11.031 
[15] I. Arpaci, "Antecedents and consequences of cloud computing adoption in education to achieve knowledge management," Computers in Human Behavior, vol. 70, 2017. https://doi.org/10.1016/j.chb.2017.01.024

[16] O. M. Yigitbasioglu, "External auditors' perceptions of cloud computing adoption in Australia," International Journal of Accounting Information Systems, vol. 18, pp. 46-62, 2015. https://doi.org/10.1016/j.accinf.2015.09.001

[17] R. Panigrahi, P. R. Srivastava, and D. Sharma, "Online learning: Adoption, continuance, and learning outcome-A review of literature," International Journal of Information Management, vol. 43, pp. 1-14, 2018. https://doi.org/10.1016/j.ijinfomgt.2018.05.005

[18] Z. Ali, R. u. Rasool, P. Bloodsworth, and S. B. Mansoor, "Facebook-based cloud resource sharing," Computers and Electrical Engineering, vol. 66, pp. 162-173, 2018. https://doi.org/10.1016/j.compeleceng.2017.11.006

[19] M. Ali, R. A. I. B. R. Yaacob, M. N. A.-A. B. Endut, and N. U. Langove, "Strengthening the academic usage of social media: An exploratory study," Journal of King Saud University - Computer and Information Sciences, vol. 29, pp. 553-561, 2017. https://doi.org/10.1 016/j.jksuci.2016.10.002

[20] V. Chang, "A cybernetics Social Cloud," The Journal of Systems and Software, vol. 124, pp. 195-211, 2017. https://doi.org/10.1016/i.jss.2015.12.031

[21] N. Jabeur, A. Nait-Sidi-Moh, and S. Zeadally, "Crowd social media computing: Applying crowd computing techniques to social media," Applied Soft Computing, vol. 66, pp. 495505, 2018. https://doi.org/10.1016/j.asoc.2017.09.026

[22] M. T. Amron, R. Ibrahim, and S. Chuprat, "A Review on Cloud Computing Acceptance Factors," presented at the 4th Information Systems International Conference 2017, ISICO 2017, Bali, Indonesia, 2017.

[23] E. Yadegaridehkordi, M. H. N. B. M. Nasir, N. F. B. M. Noor, and N. B. Liyana Shuib a, "Predicting the adoption of cloud-based technology using fuzzy analytic hierarchy process and structural equation modelling approaches," Applied Soft Computing, vol. 66, pp. 7789, 2018. https://doi.org/10.1016/j.asoc.2017.12.051

[24] F. Calisir and F. Calisir, "The relation of interface usability characteristics, perceived usefulness, and perceived ease of use to end-user satisfaction with enterprise resource planning (ERP) systems," Computers in Human Behavior vol. 20, pp. 505-515, 2004. https://doi.org/10.1016/j.chb.2003.10.004

[25] J. Shropshire, M. Warkentin, and S. Sharma, "Personality, attitudes, and intentions: Predicting initial adoption of information security behavior," c o m p u te rs \& s e curity, vol. 49, p. 177 e1 9 1, 2015. https://doi.org/10.1016/j.cose.2015.01.002

[26] S. J. Barnes and R. T. Vidgen, "Technology socialness and Web site satisfaction," Technological Forecasting \& Social Change, vol. 89, pp. 12-25, 2014. https://doi.org/10.1 016/j.techfore.2014.08.017

[27] I. Almarashdeh, "Sharing instructors experience of learning management system: A technology perspective of user satisfaction in distance learning course," Computers in Human Behavior, vol. 63, pp. 249-255, 2016. https://doi.org/10.1016/j.chb.2016.05.013

[28] Y. J. Joo, H.-J. So, and N. H. Kim, "Examination of relationships among students' selfdetermination, technology acceptance, satisfaction, and continuance intention to use KMOOCs," Computers \& Education, vol. 122, pp. 260-272, 2018. https://doi.org/10.10 16/j.compedu.2018.01.003

[29] A. U. Jan and V. Contreras, "Technology acceptance model for the use of information technology in universities," Computers in Human Behavior, vol. 27, pp. 845-851, 2011. https://doi.org/10.1016/j.chb.2010.11.009 
[30] P. Rutsaert, Z. Pieniak, Á. Regan, Á. McConnon, M. Kuttschreuter, M. Lores, et al., "Social media as a useful tool in food risk and benefit communication? A strategic orientation approach," Food Policy, vol. 46, pp. 84-93, 2014. https://doi.org/10.1 016/j.foodpol.2014.02.003

[31] G. Shanks, M. Gloet, I. A. Someh, K. Frampton, and T. Tamm, "Achieving benefits with enterprise architecture," Journal of Strategic Information Systems, vol. 27, pp. 139-156, 2018. https://doi.org/10.1016/j.jsis.2018.03.001

[32] S. N. Upadhe and D. D. Shinde, "Ease of Use Experimentation of Isometric Template," Procedia Manufacturing, vol. 20, pp. 296-299, 2018. https://doi.org/10.1 016/j.promfg.2018.02.044

[33] R. P. J. Kingshott, P. Sharma, and H. F. L. Chung, "The impact of relational versus technological resources on e-loyalty: A comparative study between local, national and foreign branded banks," Industrial Marketing Management, vol. 72, pp. 48-58, 2018. https://doi.org/10.1016/j.indmarman.2018.02.011

[34] T. D. Susanto and M. Aljoza, "Individual Acceptance of e-Government Services in a Developing Country: Dimensions of Perceived Usefulness and Perceived Ease of Use and the Importance of Trust and Social Influence," Procedia Computer Science, vol. 72, pp. 622 629, 2015. https://doi.org/10.1016/j.procs.2015.12.171

[35] Ramadiani, Azainil, U. Haryaka, F. Agus, and A. H. Kridalaksana, "User Satisfaction Model for e-Learning Using Smartphone," presented at the 2nd International Conference on Computer Science and Computational Intelligence 2017, ICCSCI 2017, Bali, Indonesia, 2017.https://doi.org/10.1016/j.procs.2017.10.070

[36] X. Zha, J. Li, and Y. Yan, "Understanding the moderating effect of tie on the transfer of ease of use and usefulness from print resources to electronic resources," Library \& Information Science Research, vol. 35, pp. 223-231, 2013. https://doi.org/10.1 016/j.lisr.2013.02.005

[37] N. Hajiheydari and M. Ashkani, "Mobile application user behavior in the developing countries: A survey in Iran," Information Systems, vol. 77, pp. 22-33, 2018https://doi.org/10. 1016/j.is.2018.05.004.

[38] G. M. Ling, Y. S. Fern, L. K. Boon, and T. S. Huat, "Understanding Customer Satisfaction of Internet Banking: A Case Study In Malacca," Procedia Economics and Finance, vol. 37, pp. 80 - 85, 2016. https://doi.org/10.1016/S2212-5671(16)30096-X

[39] Renny, S. Guritno, and H. Siringoringo, "Perceived Usefulness, Ease of use, and Attitude Towards Online Shopping Usefulness Towards Online Airlines Ticket Purchase," Procedia - Social and Behavioral Sciences, vol. 81, pp. 212 - 216, 2013. https://doi.org/10.1 016/j.sbspro.2013.06.415

[40] Y.-M. Huang, Y.-M. Huang, S.-H. Huang, and Y.-T. Lin, "A ubiquitous English vocabulary learning system: Evidence of active/passive attitudes vs. usefulness/ease-of-use," Computers \& Education, vol. 58, pp. 273-282, 2012. https://doi.org/10.1 016/j.compedu.2011.08.008

[41] S. T. Eurico, J. A. M. d. Silva, and P. O. d. Valle, "A model of graduates' satisfaction and loyalty in tourism higher education: The role of employability," Journal of Hospitality, Leisure, Sport \& Tourism Education, vol. 16, pp. 30-42, 2015. https://doi.org/10.1 016/j.jhlste.2014.07.002

[42] S. Molinillo, R. Anaya-Sánchez, R. Aguilar-Illescas, and M. Vallespín-Arán, "Social media-based collaborative learning: Exploring antecedents of attitude," The Internet and Higher Education, vol. 38, pp. 18-27, 2018. https://doi.org/10.1016/j.iheduc.2018.04.003 
[43] A. M. Aladwani, "The development of two tools for measuring the easiness and usefulness of transactional Web sites," European Journal of Information Systems, vol. 11, pp. 223234, 2002. https://doi.org/10.1057/palgrave.ejis.3000432

[44] M. A. Almaiah, M. A. Jalil, and M. Man, "Extending the TAM to examine the effects of quality features on mobile learning acceptance," Journal of Computers in Education, vol. 3, pp. 453-485, 2016. https://doi.org/10.1007/s40692-016-0074-1

[45] A. Hassanzadeh, F. Kanaani, and S. Elahi, "A model for measuring e-learning systems success in universities," Expert Systems with Applications, vol. 39, pp. 10959-10966, 2012. https://doi.org/10.1016/j.eswa.2012.03.028

[46] [46] Y. Jadeja and K. Modi, "Cloud computing - concepts, architecture and challenges," in 2012 International Conference on Computing, Electronics and Electrical Technologies (ICCEET), Kumaracoil, India, 2012, pp. 877-880. $\underline{\text { https://doi.org/10.1 }}$ 109/ICCEET.2012.6203873

[47] F. Liu, J. Tong, J. Mao, R. Bohn, J. Messina, L. Badger, et al., NIST Cloud Computing Reference Architecture: Recommendations of the National Institute of Standards and Technology (Special Publication 500-292) vol. 292. Gaithersburg, MD: Cloud Computing Program, Information Technology Laboratory, National Institute of Standards and Technology, 2012. https://doi.org/10.6028/NIST.SP.500-292

[48] P. Mell and T. Grance, The NIST definition of cloud computing recommendations of the National Institute of Standards and Technology vol. 145. Gaithersburg, MD Computer Security Division, Information Technology Laboratory, National Institute of Standards and Technology, 2011.

[49] S. S.Manvi and G. K. Shyam, "Resource management for Infrastructure as a Service (IaaS) in cloud computing: A survey," Journal of Network and Computer Applications, vol. 41, pp. 424-440, 2014. https://doi.org/10.1016/j.jnca.2013.10.004

[50] Md. Anwar Hossain Masud and X. Huang, "An E-learning System Architecture based on Cloud Computing," World Academy of Science, Engineering and Technology, vol. 62, pp. 74-78, 2012.

[51] H. F. El-Sofany, A. A. Tayeb, K. Alghatani, and S. A. El-Seoud, "The Impact of Cloud Computing Technologies in E-learning," iJET, vol. 8, pp. 37-43, 2013. https://doi.org/10.3991/ijet.v8iS1.2344

[52] J. A.González-Martínez, M. L.Bote-Lorenzo, EduardoGómez-Sánchez, and RafaelCanoParra, "Cloud computing and education: A state-of-the-art survey," Computers \& Education, vol. 80, pp. 132-151, 2015. https://doi.org/10.1016/j.compedu.2014.08.017

[53] aws. (2018, November 25). Cloud Products. Available: https://aws.amazon.com/products/?nc2=h_m1

[54] google. (2018, November 25). Google APP Engine. Available: https://cloud.google.com/appengine/

[55] Microsoft. (2018, November 25). Azure Cloud Services. Available: https://azure.microsoft.com/th-th/services/cloud-services/

[56] b. Ni. (2018, November 25). Never forget important events or information again! Available: https://nimbusweb.me/

[57] Eucalyptus. (2018, November 25). Eucalyptus. Available: https://www.eucalyptus.cloud/

[58] K. Chard, S. Caton, O. Rana, and K. Bubendorfer, "Social Cloud: Cloud Computing in Social Networks," presented at the 2010 IEEE 3rd International Conference on Cloud Computing, Miami, FL, USA, 2010. https://doi.org/10.1109/CLOUD.2010.28

[59] F. D.Davis, "User acceptance of information technology: system characteristics, user perceptions and behavioral impacts," International Journal of Man-Machine Studies, vol. 38, pp. 475-487, 1993. https://doi.org/10.1006/imms.1993.1022 
[60] M. Xia, Y. Zhang, and C. Zhang, "A TAM-based approach to explore the effect of online experience on destination image: A smartphone user's perspective," Journal of Destination Marketing \& Management, vol. 8, pp. 259-270, 2018. https://doi.org/10.1 016/j.jdmm.2017.05.002

[61] S. M. E. Sepasgozar, S. Hawken, S. Sargolzaei, and M. Foroozanfa, "Implementing citizen centric technology in developing smart cities: A model for predicting the acceptance of urban technologies," Technological Forecasting \& Social Change, 2018. https://doi.org/10.1016/j.techfore.2018.09.012

[62] C. Lisha, C. F. Goh, S. Yifan, and A. Rasli, "Integrating guanxi into technology acceptance: An empirical investigation of WeChat," Telematics and Informatics, vol. 34, pp. 1125-1142, 2017. https://doi.org/10.1016/j.tele.2017.05.003

[63] H.-Y. Y. Professor, "User Acceptance of Mobile Library Applications in Academic Libraries: An Application of the Technology Acceptance Model," The Journal of Academic Librarianship, vol. 42, pp. 687-693, 2016. https://doi.org/10.1016/j.acalib.2016.08.003

[64] F. D. Davis, "Perceived Usefulness, Perceived Ease of Use, and User Acceptance of Information Technology," MIS Quarterly, vol. 13, pp. 319-340, 1989. https://doi.org/10.2307/249008

[65] C.-C. Chang, "Library mobile applications in university libraries," Library Hi Tech, vol. 31, pp. 478-492, 2013. https://doi.org/10.1108/LHT-03-2013-0024

[66] F. Sheikhshoaei and T. Oloumi, "Applying the technology acceptance model to Iranian engineering faculty libraries," The Electronic Library, vol. 29, pp. 367-37, 2011. https://doi.org/10.1108/02640471111141106

[67] S.-J. Kim, "Factors Influencing the Intention to Use Mobile Services in Academic Libraries," Journal of the Korean BIBLIA Society for library and Information Science, vol. 25, pp. 85-105, 2014. https://doi.org/10.14699/kbiblia.2014.25.1.085

[68] Y. Xu, L. Gan, and D. Yan, "Study on Influence Factors Model of Technology Acceptance in Digital Library Based on User Cognition and TAM," presented at the 2010 International Conference on Management and Service Science, Wuhan, China, 2010. https://doi.org/10.1109/ICMSS.2010.5576775

[69] T. Amornkitpinyo and P. Piriyasurawong, "Causal Relationship Model of the Information and Communication Technology Skill Affect the Technology Acceptance Process in the 21st Century for Undergraduate Students," iJET, vol. 10, pp. 68-71, 2015. https://doi.org/10.3991/ijet.v10i1.4185

[70] S. Joo and N. Choi, "Factors affecting undergraduates' selection of online library resources in academic tasks: Usefulness, ease-of-use, resource quality, and individual differences," Library Hi Tech, vol. 33, pp. 272-291, 2015. https://doi.org/10.1108/LHT-01-2015-0008

[71] A. Bhattacherjee, "Understanding Information Systems Continuance: An ExpectationConfirmation Model," MIS Quarterly, vol. 25, pp. 351-370, 2001. https://doi.org/10.2307/3250921

[72] E. Park and K. J. Kim, "User acceptance of long-term evolution (LTE) services: An application of extended technology acceptance model," Program, vol. 47, pp. 188-205, 2013. https://doi.org/10.1108/00330331311313762

[73] W. Delone and E. McLean, "The DeLone and McLean Model of Information Systems Success: A Ten-Year Update," Journal of Management Information Systems vol. 19, pp. 930, 2003. https://doi.org/10.1080/07421222.2003.11045748

[74] T. MinLee and CheolPark, "Mobile technology usage and B2B market performance under mandatory adoption," Industrial Marketing Management, vol. 37, pp. 833-840, 2008. https://doi.org/10.1016/j.indmarman.2008.02.008 


\section{Authors}

Supparang Ruangvanich, she got the bachelor's degree in business administration and graduated the master's degree on Computer and Engineering Management, Assumption University of Thailand. She works as a lecturer in Multimedia Technology, Faculty of Science at Chandrakasem Rajabhat University, Bangkok, Thailand, 10900 (supparang.r@chandra.ac.th). She is interested in learning analytics, cloud technology, mobile learning, digital media.

Pallop Piriyasurawong is an Associate Professor of Division of Information and Communication Technology for Education, Faculty of Technical Education, KingMongkut's University of Technology North Bangkok (KMUTNB), Bangkok, Thailand, 10800 (e-mail: palloppi@gmail.com). He has experience in many positions such as Computer curriculum specialist at Basic Education Institute for the Promotion of Teaching Science and Technology (IPST). And he is Chairman of the Board of Courseware Series of Teaching in Undergraduate Information Technology Systems, e-Learning of Office the Higher Education Commission. Also, he is a director of Division of Information and Communication Technology for Education.

Article submitted 2018-12-23. Resubmitted 2019-01-26. Final acceptance 2019-02-13. Final version published as submitted by the authors. 